\title{
ANALISIS INTERFERENSI SINTAKSIS BAHASA DAERAH SIKKA PADA KARANGAN NARASI PESERTA DIDIK
}

\section{ANALYSIS OF SYNACTIC INTERFERENCE OF SIKKA REGIONAL LANGUAGE IN THE NARRATION OF NARRATIVE STUDENTS}

\author{
Agustina Maria Lidi ${ }^{1 *}$ Robertus Adi Sarjono Owon ${ }^{2)}$ Bernadus Bura ${ }^{3)}$ \\ 1,2,3 Jurusan Pendidikan Bahasa dan Sastra Indonesia, Fakultas Pendidikan Ilmu Sosial \\ dan Humaniora, IKIP Muhammadiyah Maumere \\ ${ }^{1}$ Email : agustinamarialidi9708@gmail.com
}

\begin{abstract}
ABSTRAK
Penelitian ini bertujuan mengetahui bentuk interferensi sintaksis bahasa daerah Sikka pada karangan narasi peserta didik. Penelitian ini menggunakan metode kualitatif. Teknik pengumpulan data dalam penelitian ini adalah observasi (pengamatan), teknik baca dan teknik catat. Teknik analisis data pada penelitian ini adalah data hasil karangan narasi peserta didik. Data tersebut dianalisis dengan cara membaca, memeriksa, menilai dan mengelompokkan kalimat yang di dalamnya terdapat interferensi sintaksis. Sumber data dalam penelitian ini adalah tulisan atau karangan narasi peserta didik di SMPK Sanctissima Trinitas Bloro kelas VII yang berada di dalam kelas saat pembelajaran bahasa Indonesia. Data yang dianalisis adalah frase, klausa dan kalimat yang diduga mengandung interferensi bahasa Sikka ke dalam bahasa Indonesia. Berdasarkan hasil penelitian terdapat interferensi sintaksis pada karangan narasi peserta didik. Temuan penelitian ini juga menunjukkan bahwa banyak yang terinterferensi pada bentuk frase, klausa dan kalimat. Dari kejadian ini dapat dikatakan bahwa peserta didik memiliki pengetahuan yang minim mengenai bentuk dan pola struktur penulisan bahasa Indonesia yang baik dan benar. Oleh karena itu, kalimat yang digunakan dalam menulis kurang efektif dan tidak sesuai dengan struktur penulisan bahasa Indonesia yang baku.
\end{abstract}

Kata kunci: Interferensi Sintaksis, Karangan Narasi, Bahasa Sikka

\begin{abstract}
This study aims to determine the form of Sikka regional language syntactic interference in the narrative essays of students. This study uses a qualitative method. Data collection techniques in this study were observation, reading and note taking techniques. The data analysis technique in this study was the data written by students' narratives. The data is analyzed by reading, checking, assessing and grouping sentences in which there is syntactic interference. The data source in this study is the writing or essay of the students' narratives at the VII grade Sanctissima Trinity Bloro Middle School who are in the classroom when learning Indonesian. The data analyzed are phrases, clauses and sentences that are suspected to contain Sikka language interference into Indonesian. Based on the results of the study there is syntactic interference in students' narrative essays. The findings of this study also indicate that many are interfered with in the form of phrases, clauses and sentences. From this incident it can be said that students have minimal knowledge about the forms and patterns of Indonesian language writing structures that are good and right. Therefore, the sentences used in writing are less effective and do not fit into the standard Indonesian writing structure.
\end{abstract}


P-ISSN 2580 - 7781

E-ISSN $2615-3238$

Keywords: Syntactic Interference, Narrative Essay, Sikka Language

\section{PENDAHULUAN}

Bahasa Indonesia merupakan bahasa yang sah dan dijadikan sebagai bahasa nasional sejak dibebaskan dari penjajahan (Ramendra, 2013, 275). Setiap bahasa memberi tanda dan petunjuk bahwa adanya norma sopan santun berbahasa yang baik dan ketat. Bahasa dijadikan sebagai media untuk berkomunikasi dan berhubungan antara sesama karena manusia merupakan makhluk bermasyarakat dan berbudaya. Bahasa adalah suatu lambang bunyi yang digunakan oleh masyarakat untuk berkomunikasi. Ada dua pengertian bahasa yaitu (1) bahasa sebagai lambang bunyi yang yang dihasilkan oleh alat ucap manusia yang mengandung makna, (2) bahasa sebagai arti atau makna yang menyebabkan adanya suatu reaksi atau respon dari orang yang mendengar. Oleh sebab itu, arus bunyi atau lambang bunyi disebut arus ujaran (Ritonga, 2012, 1).

Apabila bahasa berubah, tidak tetap serta tidak statis maka kehidupan manusia dalam bermasyarakatpun akan selalu berubah. Oleh karena itu, perubahan bahasa bisa terjadi dalam bidang fonologi, morfologi, sintaksis, semantik dan leksikon. Perkembangan bahasa Indonesia mengalami perubahan ejaan misalnya Van Ophuysen, Soewandi, Pembaruan, dan Ejaan Yang Disempurnakan (EYD). Perubahan tersebut dapat dilihat, misalnya pada Ejaan Van Ophuysen penggunaan huruf u diwakili oleh dua vokal yakni o dan e (Soeharto dibaca Suharto) dan Ejaan Soewandi bunyi j di tulis dengan dua konsonan yaitu d dan j (Djoko dibaca Joko). Penggunaan Ejaan Van Ophuysen dan Ejaan Soewandi sampai saat ini masih mempengaruhi ejaan yang disempurnakan. Misalnya sering kita mendengar bunyi huruf ce diucapkan se, qi diucapkan qui. Sebaliknya kaum milenial mengucapkan huruf je yang dulu dibaca ye tetap diucapkan je oleh kaum milenial. Orang yang bernama Johanis seharusnya dibaca Yohanes tetap diucapkan Johanis. Interferensi seperti ini terjadi pada penggunaan bahasa Indonesia antarmasa, serta pada bahasa yang satu dengan yang lain. Hal ini sejalan dengan judul tulisan penulis yaitu interferensi sintaksis bahasa daerah Sikka pada karangan narasi peserta didik. 
Interferensi adalah percampuran sistem bahasa ke dalam sistem bahasa lainnya (Daeng, 2011, 252). Selain itu, interferensi merupakan terjadinya kontak bahasa yang menimbulkan pengaruh terhadap penggunaan bahasa lain (Achmad dan Abdullah, 2012, 180). Penyebab terjadinya interferensi adalah salah dalam memilih bahasa, latar belakang daerah siswa, kecakapan dalam menggunakan bahasa dan dipengaruhi juga dengan bahasa guru (Lubis, 2012, 6). Bukan hanya itu, faktor yang mempengaruhi interferensi yaitu kembali pada kemampuan si penutur dalam menggunakan suatu bahasa sehingga dipengaruhi oleh bahasa lain. Misalnya terjadi pada penggunaan bahasa Indonesia (B2) dan bahasa ibu (B1) yang mempengaruhi penggunaan B2.

Interferensi adalah suatu penyimpangan bahasa karena dalam pelaksanaan secara nyata oleh si penutur tetap menggunakan unsur bahasa lain. Akan tetapi, gejala interferensi tidak hanya disebabkan oleh percampuran budaya, melainkan dipengaruhi oleh kemampuan serta konsistensi penutur dalam menggunakan suatu bahasa. Pada suatu pengembangan bahasa, interferensi merupakan salah satu fenomena yang banyak memberikan kontribusi dalam hal pengembangan bahasa dan kosa kata. Hal ini disebabkan oleh manusia yang menggunakan suatu bahasa dituntut untuk mengetahui dan memahami suatu bahasa tertentu. Oleh karena itu, interferensi mampu mengungkapkan hal-hal yang belum terungkap dari suatu bahasa melalui suatu komunikasi.

Dwibahasawan dan multilingual merupakan orang yang menggunakan lebih dari dua bahasa secara bergantian menimbulkan keinginan untuk memasukkan unsur bahasa yang satu pada bahasa lainnya, sehingga bertentangan dengan aturan bahasa (Junus dan Fatimah, 2010, 30). Melalui uraian tersebut, maka dapat dibenarkan bahwa peristiwa dapat diamati melalui percakapan (secara lisan) dan secara tertulis yang dilakukan oleh peserta didik. Fokus dalam penelitian ini adalah interferensi pada bahasa tulis peserta didik. Bahasa tulis lebih mudah diamati daripada bahasa lisan. Bidang morfologi dan sintaksis termasuk dalam ranah tata bahasa atau gramatikal. Interferensi dianggap sebagai penyimpangan norma bahasa yang terjadi di dalam ujaran dwibahasawan karena keakrabannya 
P-ISSN 2580 - 7781

E-ISSN $2615-3238$

terhadap lebih dari satu bahasa yang menyebabkan terjadinya kontak bahasa (Junus dan Fatimah, 2010, 32).

\section{METODE PENELITIAN}

Penelitian ini menggunakan metode kualitatif. Metode kualitatif merupakan suatu penelitian yang dilakukan untuk menjelaskan suatu data yang ditemukan dari objek penelitian (Chaer, 2011, 183). Oleh karena itu, metode penelitian kualitatif juga digunakan untuk memperoleh pemahaman mengenai suatu gejala yang terjadi dalam masyarakat (Wijayanti, 2013, 222).

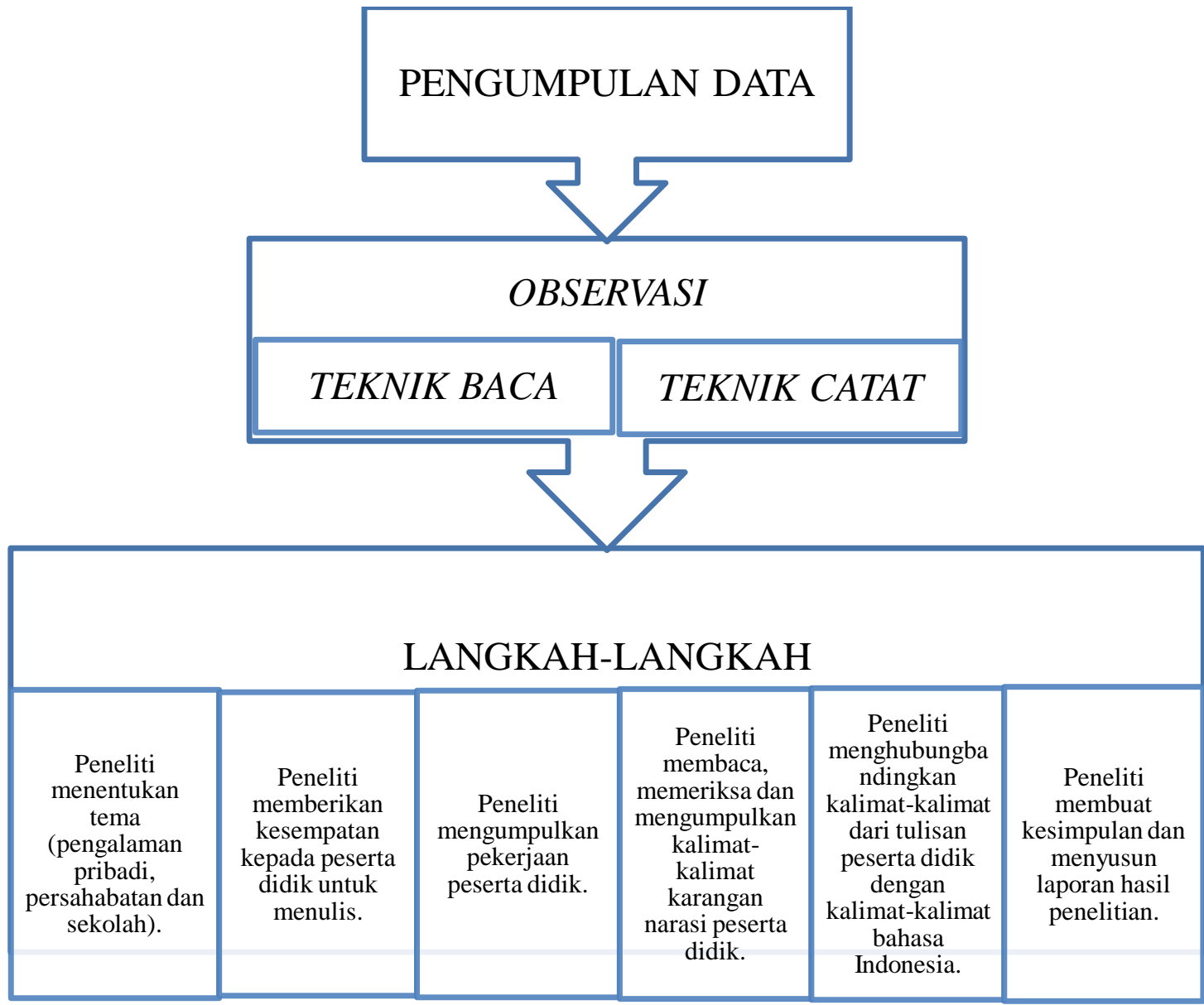


P-ISSN 2580 - 7781

E-ISSN $2615-3238$

\section{HASIL PENELITIAN DAN PEMBAHASAN}

Penelitian ini dilakukan untuk mendeskripsikan analisis interferensi sintaksis pada karangan narasi Peserta Didik. Hasil penelitian ini, akan disesuaikan dengan tujuan penelitian dan selanjutnya dilakukan pembahasan terhadap hasil penelitian secara kualitatif. Metode penelitian kualitatif digunakan untuk memperoleh pemahaman mengenai suatu gejala yang terjadi dalam masyarakat. Data diambil dari karangan narasi peserta didik dan dideskripsikan dengan teori yang digunakan. Penelitian tersebut didasarkan pada tujuan penelitian yaitu untuk mengetahui bentuk interferensi bahasa daerah pada karangan narasi peserta didik. Berikut ini, data yang diperoleh peneliti mengenai interferensi dapat dilihat pada tabel 1 .

Tabel 1. Interferensi Kalimat dan Klausa

\begin{tabular}{|c|c|c|c|c|c|}
\hline \multirow{2}{*}{ No. } & \multirow{2}{*}{$\begin{array}{l}\text { Kode } \\
\text { Data }\end{array}$} & \multicolumn{2}{|c|}{ Indonesia } & \multirow{2}{*}{ Sikka } & \multirow{2}{*}{ Interferensinya } \\
\hline & & Siswa & Baku & & \\
\hline 1. & NK 01 & $\begin{array}{l}\text { Kami sangat } \\
\text { akrab maupun } \\
\text { di rumah dan } \\
\text { sekolah. }\end{array}$ & $\begin{array}{l}\text { Kami sangat } \\
\text { akrab baik di } \\
\text { rumah maupun } \\
\text { di sekolah. }\end{array}$ & $\begin{array}{l}\text { Ami imung } \\
\text { wi'in pu'an ei } \\
\text { orin da'a ei } \\
\text { sekolah. }\end{array}$ & $\begin{array}{l}\text { Imung wi'in yang } \\
\text { artinya sangat } \\
\text { akrab }\end{array}$ \\
\hline 2. & NK 02 & $\begin{array}{l}\text { Saya dan } \\
\text { teman sampai } \\
\text { di rumah } \\
\text { keluarga dari } \\
\text { ibu saya. }\end{array}$ & $\begin{array}{l}\text { Saya dan teman } \\
\text { singga di rumah } \\
\text { keluarga ibuku. }\end{array}$ & $\begin{array}{l}\text { A'u ora imung } \\
\text { ma da'a ei orin } \\
\text { ina a'un wuen } \\
\text { warin. }\end{array}$ & 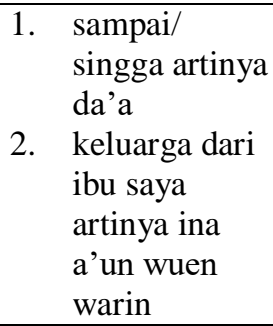 \\
\hline 3. & NK 03 & $\begin{array}{l}\text { Setelah makan } \\
\text { semua orang } \\
\text { berpindah } \\
\text { tempat, yang } \\
\text { lain duduk } \\
\text { berbincang, } \\
\text { yang lain } \\
\text { duduk nonton } \\
\text { TV. }\end{array}$ & $\begin{array}{l}\text { Setelah makan } \\
\text { semua orang } \\
\text { berpindah } \\
\text { tempat, yang } \\
\text { lain duduk } \\
\text { berbincang, } \\
\text { yang lain duduk } \\
\text { nonton TV }\end{array}$ & $\begin{array}{l}\text { A sawe ata } \\
\text { mogan sawen } \\
\text { dese olang, iwa } \\
\text { teri nora } \\
\text { babong iwa, } \\
\text { teri pile TV. }\end{array}$ & $\begin{array}{l}\text { 1. setelah makan } \\
\text { artinya a sawe } \\
\text { 2. berpindah } \\
\text { tempat } \\
\text { artinya dese } \\
\text { olang }\end{array}$ \\
\hline 4. & NK 04 & $\begin{array}{l}\text { Mendengar itu } \\
\text { saya merasa } \\
\text { sangat senang } \\
\text { karena berlibur }\end{array}$ & $\begin{array}{l}\text { Mendengar hal } \\
\text { itu, saya merasa } \\
\text { sangat senang } \\
\text { karena berlibur }\end{array}$ & $\begin{array}{l}\text { êna ia a'u 'rasa } \\
\text { une waten } \\
\text { bliran loning } \\
\text { libur ia }\end{array}$ & $\begin{array}{l}\text { êna ia artinya } \\
\text { mendengar itu. }\end{array}$ \\
\hline
\end{tabular}


P-ISSN 2580 - 7781

E-ISSN 2615 - 3238

\begin{tabular}{|c|c|c|c|c|c|}
\hline & & $\begin{array}{l}\text { itu } \\
\text { menyenangkan. }\end{array}$ & $\begin{array}{l}\text { itu } \\
\text { menyenangkan. }\end{array}$ & menyenangkan. & \\
\hline 5. & NK 05 & $\begin{array}{l}\text { Di rumah } \\
\text { nenek, ia } \\
\text { mengajakku } \\
\text { berjalan-jalan } \\
\text { keliling } \\
\text { kampung, pergi } \\
\text { ke kebun dan } \\
\text { ke rumah } \\
\text { keluarga. }\end{array}$ & $\begin{array}{l}\text { Di rumah nenek, } \\
\text { ia mengajakku } \\
\text { berjalan-jalan } \\
\text { keliling } \\
\text { kampung, ke } \\
\text { kebun dan ke } \\
\text { rumah keluarga. }\end{array}$ & $\begin{array}{l}\text { Ei ina du'a orit, } \\
\text { nimu leta a'u } \\
\text { pano gole } \\
\text { giling natar, ma } \\
\text { ei uma ma ei } \\
\text { orin wue wari. }\end{array}$ & $\begin{array}{l}\text { Di rumah nenek } \\
\text { artinya ei ina du'a } \\
\text { orit. }\end{array}$ \\
\hline 6. & NK 06 & $\begin{array}{l}\text { Pada suatu hari } \\
\text { saya dan } \\
\text { teman-teman } \\
\text { saya pergi ke } \\
\text { nanga. }\end{array}$ & $\begin{array}{l}\text { Pada suatu hari, } \\
\text { saya dan teman- } \\
\text { teman pergi ke } \\
\text { Nanga. }\end{array}$ & $\begin{array}{l}\text { Nora leron ha } \\
\text { a'u ora imung } \\
\text { deung a'un } \\
\text { pano ei nanga. }\end{array}$ & $\begin{array}{l}\text { Teman-teman saya } \\
\text { artinya imung- } \\
\text { imung a'ut. }\end{array}$ \\
\hline 7. & NK 07 & $\begin{array}{l}\text { Kami melihat } \\
\text { banyak orang } \\
\text { yang lagi } \\
\text { mandi, ada } \\
\text { yang lagi foto- } \\
\text { foto, ada pula } \\
\text { yang lagi } \\
\text { bakar-bakar } \\
\text { ikan. }\end{array}$ & $\begin{array}{l}\text { Kami melihat } \\
\text { banyak orang } \\
\text { yang lagi mandi, } \\
\text { ada yang foto- } \\
\text { foto, ada pula } \\
\text { yang bakar ikan }\end{array}$ & $\begin{array}{l}\text { Ami gita ata } \\
\text { riwun 'era hu'i, } \\
\text { iwa foto-foto, } \\
\text { iwa rope i'an. }\end{array}$ & $\begin{array}{l}\text { Kami melihat } \\
\text { banyak orang } \\
\text { artinya ami gita } \\
\text { ata riwun. }\end{array}$ \\
\hline 8. & NK 08 & $\begin{array}{l}\text { Sesampai } \\
\text { makan habis, } \\
\text { Andre mau } \\
\text { pulang ke } \\
\text { rumah. }\end{array}$ & $\begin{array}{l}\text { Setelah selesai } \\
\text { makan, Andre } \\
\text { ingin pulang ke } \\
\text { rumahnya. }\end{array}$ & $\begin{array}{l}\text { Gea sawe, } \\
\text { Andre ga'i } \\
\text { balong ei orin. }\end{array}$ & $\begin{array}{l}\text { Makan habis } \\
\text { artinya gea sawe. }\end{array}$ \\
\hline 9. & NK 09 & $\begin{array}{l}\text { Setelah mandi } \\
\text { ayahnya Devan } \\
\text { mengajak kami } \\
\text { pulang karena } \\
\text { sudah siang. }\end{array}$ & $\begin{array}{l}\text { Setelah mandi, } \\
\text { ayahnya Devan } \\
\text { mengajak kami } \\
\text { pulang karena } \\
\text { hari sudah mulai } \\
\text { siang. }\end{array}$ & $\begin{array}{l}\text { Hu'i sawe } \\
\text { Defan amat } \\
\text { leta ami balong } \\
\text { loning lero } \\
\text { detu ba'a. }\end{array}$ & 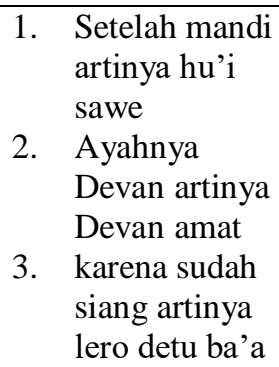 \\
\hline 10. & NK 10 & $\begin{array}{l}\text { Kami } \\
\text { mendengar } \\
\text { suara motor } \\
\text { dari bawah } \\
\text { rabat. }\end{array}$ & $\begin{array}{l}\text { Kami } \\
\text { mendengar suara } \\
\text { motor dari arah } \\
\text { jalan rabat. }\end{array}$ & $\begin{array}{l}\text { Ami rena } \\
\text { motor lin wawa } \\
\text { rabat wawa } \\
\text { main. }\end{array}$ & $\begin{array}{l}\text { Dari bawah rabat } \\
\text { artinya wawa } \\
\text { rabat. }\end{array}$ \\
\hline
\end{tabular}


Berdasarkan tabel tersebut dapat diketahui bahwa terdapat 10 kalimat dari karangan peserta didik yang mengalami interferensi. Interferensi kalimat ini terjadi karena struktur kalimat bahasa daerah Sikka Krowe yang mirip dengan struktur kalimat dalam Bahasa Indonesia yakni terdiri dari fungsi subjek, predikat, objek, dan keterangan. Begitu juga dengan interferensi klausa yang merupakan satuan sintaksis berupa runtunan kata-kata berkonstruksi predikatif. Konstruksi tersebut mempunyai komponen yaitu kata atau frasa yang berfungsi sebagai subjek, objek dan keterangan. Jadi, inteferensi kalimat itu adalah interferensi klausa itu sendiri. Alasannya karena dalam klausa itu bisa satu, dua atau bahkan tiga kalimat.

Kalimat merupakan satuan bahasa berupa wujud lisan dan tulisan yang mengungkapkan pikiran yang utuh (Alwi, 2014, 317). Kalimat yang diucapkan dengan suara naik turun dan keras lembut di sela jeda, diakhiri dengan intonasi akhir yang diikuti oleh kesenyapan yang mencegah terjadinya perpaduan ataupun asimilasi bunyi dan proses fonologis lainnya disebut sebagai wujud lisan. Dalam wujud tulisan, kalimat dimulai dengan huruf kapital dan diakhiri dengan tanda titik, tanda tanya dan tanda seru. Sedangkan, klausa adalah satuan sintaksis berupa runtunan kata atau frasa yang berfungsi sebagai subjek, predikat, objek dan keterangan. Selain itu, fungsi predikat yang harus ada dalam susunan klausa yaitu fungsi subjek bersifat wajib, sedangkan yang lainnya bersifat tidak wajib (Chaer, 2012, 231).

(NK 01) Kami (S) sangat akrab (P) maupun di rumah dan sekolah (Ket.tempat). Apabila diterjemahkan dalam bahasa Sikka dan ditentukan struktur kalimatnya maka, Ami (S) imung wi'in (P) pu'an ei orin da'a ei sekolah (Ket.tempat). Yang menjadi interferensi adalah dari kata imung wi'in yang artinya sangat akrab. Penulisan kalimat yang benar adalah "Kami sangat akrab baik di rumah maupun di sekolah". Dan memiliki dua klausa yaitu $\operatorname{Kami}(S)$ akrab $(P) d i$ rumah (Ket.tempat)(1), akrab pula $(P)$ disekolah (Ket.tempat) (2) sedangkan Ami (S) imung wi'in (P) (1) pu'an ei orin da'a ei sekolah (Ket.tempat) (2).

(NK 02) Saya (S1) dan teman (S2) sampai (P) di rumah (Ket.tempat) keluarga dari ibu saya (Ket.asal). Apabila diterjemahkan dalam bahasa Sikka dan 
P-ISSN 2580 - 7781

E-ISSN $2615-3238$

ditentukan struktur kalimatnya maka, A'u (S) ora (P1) imung (O) ma da'a (P2) ei orin (Ket.tempat) ina a'un wuen warin (Ket.milik). Kalimat ini adalah pengaruh inteferensi langsung dari bahasa Sikka. Bahkan diterjemahkan dari kata demi kata. Yang menjadi interferensi adalah dari kata sampai/ singga artinya $d a{ }^{\prime} a$ dan keluarga dari ibu saya artinya ina a'un wuen warin. Kalimat terjemahan dalam bahasa Indonesia yang baik adalah "Saya dan teman singga di rumah keluarga ibuku”. Kedua kalimat tersebut memiliki dua klausa yaitu $\underline{S a y a}(S)$ membawa $(P)$ teman $(S)(1)$ dan singga $(P)$ di rumah (Ket.tempat) keluarga ibuku (Ket.asal) (2)

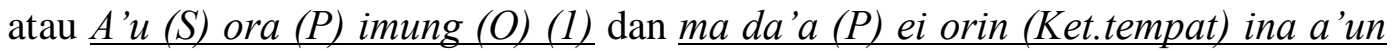
wuen warin (Ket.milik) (2).

(NK 03) Setelah makan (P1) semua orang (S1) berpindah tempat (P2), yang lain (S2) duduk berbincang (P3), yang lain (S3) duduk nonton TV (P4). Apabila diterjemahkan dalam bahasa Sikka dan ditentukan struktur kalimatnya maka, $A$ sawe (P1) ata mogan sawen (S1) dese olang (P2), iwa (S2) teri nora babong (P3), iwa (S3) teri pile TV (P4). Kalimat ini adalah pengaruh atau inteferensi langsung dari bahasa Sikka. Bahkan diterjemahkan dari kata demi kata. Yang menjadi interferensi adalah setelah makan artinya a sawe dan berpindah tempat artinya dese olang. Hal yang menjadi penyebab terjadinya interferensi tersebut adalah kehilangan penulisan subjek. Misalnya a sawe, dalam kata $a$ terdiri atas subjek dan predikat, $a$ dalam hal ini merupakan mereka yang makan. Begitu juga dengan dese olang yang menjadi subjeknya adalah rimu artinya mereka yang berpindah tempat. Maka kalimat terjemahan dalam bahasa Indonesia yang benar adalah "Setelah makan semua orang berpindah tempat, yang lain duduk berbincang, yang lain duduk nonton TV". Dan memiliki empat klausa yaitu, setelah makan (P1) (1), semua orang (S1) berpindah tempat (P2) (2), yang lain (S2) duduk berbincang (P3) (3) dan yang lain (S3) duduk nonton TV (P4) (4) sedangkan $\underline{A}$ sawe (P) (1), ata mogan sawen $(S)$ dese olang $(P)(2)$, iwa $(S)$ teri nora babong $(P)(3)$, dan iwa (S) teri pile TV $(P)(4)$.

(NK 04) Mendengar (P1) itu (O) saya (S1) merasa (P2) sangat senang (Ket.suasana) karena berlibur itu (S2) menyenangkan (P3). Apabila diterjemahkan dalam bahasa Sikka dan ditentukan struktur kalimatnya maka, êna ia (P) a'u (S) 
P-ISSN 2580 - 7781

E-ISSN 2615 - 3238

'rasa une waten bliran loning libur ia menyenangkan $(O)$. Kalimat ini adalah pengaruh atau inteferensi langsung dari bahasa Sikka. Bahkan diterjemahkan dari kata demi kata. Yang menjadi interferensi yaitu êna ia artinya mendengar itu. Hal ini terjadi karena pada kata êna mempunyai subjek dan predikat. Yang menjadi subjek itu adalah saya. Oleh karena itu, penulisan yang benar adalah "Mendengar hal itu, saya merasa sangat senang karena berlibur itu menyenangkan". Dan memiliki tiga klausa yaitu, mendengar $(P 1)$ hal itu $(O)(1)$, saya (S1) merasa (P2) sangat senang(Ket.suasana) (2) dan karena êberlibur itu (S2) menyenangkan (P) (3) sedangkan êna ia (P) (1), a'u (S) 'rasa une waten bliran(Ket.suasana) (2), dan loning libur ia menyenangkan $(O)(3)$.

(NK 05) Di rumah nenek (Ket.tempat), ia (S) mengajakku (P1) berjalanjalan (P2) keliling kampung (P3), pergi (P4) ke kebun (Ket.tempat) dan ke rumah keluarga (P5). Apabila diterjemahkan dalam bahasa Sikka dan ditentukan struktur kalimatnya maka, Ei ina du'a orit (Ket.tempat), nimu (S) leta $(P)$ a'u $(O)$ pano $(P)$ gole giling (Ket.aktifitas) natar (Ket.tempat), ma $(P)$ ei uma (Ket.tempat) ma $(P)$ ei orin wue wari (Ket.tempat). Kalimat ini adalah pengaruh inteferensi langsung dari bahasa Sikka. Yang menjadi interferensi adalah di rumah nenek artinya ei ina du'a orit. Misalnya pada kata orit mempunyai arti bahwa kepunyaan. Maka penulisan dalam bahasa Indonesia yang benar adalah "Di rumah nenek, ia mengajakku berjalan-jalan keliling kampung, ke kebun dan ke rumah keluarga". Kedua kalimat tersebut memilki empat klausa yaitu Di rumah nenek (Ket.tempat) (1) ia (S) mengajakku (P1) berjalan-jalan (P2) keliling kampung (P3) (2), pergi (P4) ke kebun (Ket.tempat) (3), dan ke rumah keluarga (P5) (4) atau Ei ina du'a orin (Ket.tempat) (1), nimu (S) leta $(P)$ a'u $(O)$ pano (P) gole giling (Ket.aktifitas) $\underline{\text { natar (Ket.tempat) (2), ma (P) ei uma (Ket.tempat) (3), ma (P) ei orin wue wari }}$ (Ket.tempat) (4).

(NK 06) Pada suatu hari (Ket.waktu) saya (S1) dan teman-teman saya (S2) pergi (P) ke nanga (Ket.tempat). Apabila diterjemahkan dalam bahasa Sikka dan ditentukan struktur kalimatnya maka, Nora leron ha (ket. waktu) a'u ora imung deung a'un (S) pano ei nanga (ket.tempat). Kalimat ini adalah pengaruh inteferensi langsung dari bahasa Sikka. Yang menjadi interferensi adalah teman- 
P-ISSN 2580 - 7781

E-ISSN $2615-3238$

teman saya artinya imung-imung a'ut. Maka penulisan dalam bahasa indonesia yang baik adalah "Pada suatu hari, saya dan teman-teman pergi ke Nanga". Dan mempunyai dua klausa yaitu, pada suatu hari (Ket.waktu) (1), saya dan temanteman (S) pergi ke Nanga (Ket.tempat) (2) atau Nora leron ha (ket. Waktu (1)), dan a'u ora imung deung a'un (S) pano ei nanga (ket. tempat) (2).

(NK 07) Kami (S) melihat (P) banyak orang (O) yang lagi mandi (Ket.keadaan), ada yang lagi foto-foto(Ket.keadaan), ada pula yang lagi bakarbakar ikan (Ket.keadaan). Apabila diterjemahkan dalam bahasa Sikka dan ditentukan struktur kalimatnya maka, Ami $(S)$ gita $(P)$ ata riwun (Ket.jumalah) 'era hu'i (Ket.keadaan), iwa foto-foto (Ket.keadaan), iwa rope i'an (Ket.keadaan). Kalimat ini adalah pengaruh inteferensi langsung dari bahasa Sikka. Yang menjadi interferensi adalah kami melihat banyak orang artinya ami gita ata riwun. Penulisan kalimat yang benar "Kami melihat banyak orang yang lagi mandi, ada yang foto-foto, ada pula yang bakar ikan”. Dan mempunyai tiga klausa yaitu, $\underline{\operatorname{Kami}}(S)$ melihat $(P)$ banyak orang (Ket.jumlah) yang lagi mandi (Ket.keadaan) (1), ada yang lagi foto-foto(Ket.keadaan) (2), ada pula yang lagi bakar-bakar ikan (Ket.keadaan) (3), atau $\underline{A m i}(S)$ gita $(P)$ ata riwun (Ket.jumalah) 'era hu'i (Ket.keadaan) (1), iwa foto-foto (Ket.keadaan) (2), iwa nope-nope i'an (Ket.keadaan) (3).

(NK 08) Sesampai makan (P1) habis (O), Andre (S) mau pulang (P2) ke rumah (Ket.tempat). Apabila diterjemahkan dalam bahasa Sikka dan ditentukan struktur kalimatnya maka, Gea (P1) sawe (O), Andre (S) ga'i balong (P2) ei orin (Ket.tempat). Kalimat ini adalah pengaruh inteferensi langsung dari bahasa Sikka. Yang menjadi interferensi adalah makan habis artinya gea sawe. Hal ini terjadi karena dari kata gea mempunya subjek, predikat dan keterangan waktu. Maka penulisan yang benar adalah "Setelah selesai makan, Andre ingin pulang ke rumahnya. Dan kedua kalimat tersebut mempunyai dua klausa yaitu Sesampai makan (P1) habis (O) (1), Andre (S) mau pulang (P2) ke rumah (Ket.tempat) (2) sedangkan Gea (P1) sawe (O) (1), Andre (S) ga'i balong (P2) ei orin (Ket.tempat) (2). 
(NK 09) Setelah mandi (P) ayahnya Devan (S) mengajak (P2) kami pulang (O) karena sudah siang (Ket.waktu). Apabila diterjemahkan dalam bahasa Sikka dan ditentukan struktur kalimatnya maka, Hu'i sawe (P) Defan amat (S) leta (P2) ami balong $(\mathrm{O})$ loning lero detu ba'a (Ket.waktu). Kalimat ini adalah pengaruh inteferensi langsung dari bahasa Sikka. Yang menjadi interferensi adalah setelah mandi artinya hu'i sawe, ayahnya Devan artinya Devan amat dan karena sudah siang artinya lero detu ba'a. Dalam hal ini kata $h u$ 'i tidak diketahui subjeknya, Devan amat juga mempunyai pengaruh terhadap penulisan tersebut karena tidak memiliki kejelasan nama ayah tersebut. Sedangkan lero detu juga ada subjeknya yaitu lero/ hari dan detu/ siang. Maka penulisan yang benar adalah "Setelah mandi, ayahnya Devan mengajak kami pulang karena hari sudah mulai siang". Kalimat tersebut memiliki tiga klausa yaitu, Setelah mandi $(P)(1)$ ayahnya Devan (S) mengajak (P2) kami pulang (O) (2) karena sudah siang (Ket.waktu) (3) sedangkan $\underline{H u}$ 'i sawe $(P)(1)$ Defan amat $(S)$ leta $(P 2)$ ami balong $(O)$ (2) loning lero detu ba'a (Ket.tempat) (3).

(NK 10) Kami $(S)$ mendengar $(P)$ suara motor $(O)$ dari bawah rabat (Ket.tempat). Apabila diterjemahkan dalam bahasa Sikka dan ditentukan struktur kalimatnya maka, Ami $(S)$ rena $(P)$ motor lin $(O)$ wawa rabat wawa main (Ket.tempat). Kalimat ini adalah pengaruh inteferensi langsung dari bahasa Sikka. Yang menjadi interferensi adalah dari bawah rabat artinya wawa rabat. Penulisan kalimat yang benar adalah "Kami mendengar suara motor dari arah jalan rabat". Dan memiliki dua klausa yaitu, $\underline{\operatorname{Kami}}(S)$ mendengar $(P)$ suara motor $(O(1)$ dari bawah rabat (Ket.tempat) (2) sedangkan Ami $(S)$ rena $(P)$ motor lin $(O(1)$ wawa rabat wawa main (Ket.tempat) (2).

Hasil analisis terhadap karangan narasi peserta didik kelas VII di SMPK Sanctissima Trinitas Bloro dapat diketahui bahwa adanya interferensi kalimat dan klausa. Struktur penulisannya tidak efektif atau tidak bertaruran, karena penggunaan bahasa daerah Sikka yang mempunyai pengaruh terhadap bahasa Indonesia. Struktur penulisan sebuah kalimat yang tepat adalah subjek, predikat, objek, dan keterangan. 
P-ISSN 2580 - 7781

E-ISSN $2615-3238$

Selanjutnya, pada tulisan peserta didik ditemukan pula interferensi frase yang dapat dibaca pada tabel 2 .

Tabel 2. Interferensi Frase

\begin{tabular}{|c|c|c|c|c|c|}
\hline \multirow{2}{*}{ No. } & \multirow{2}{*}{$\begin{array}{l}\text { Kode } \\
\text { Data }\end{array}$} & \multicolumn{2}{|c|}{ Indonesia } & \multirow{2}{*}{ Sikka } & \multirow{2}{*}{ Interferensinya } \\
\hline & & Siswa & Baku & & \\
\hline 1. & NK 02 & Rumah keluarga & $\begin{array}{l}\text { Rumah } \\
\text { keluarga }\end{array}$ & $\begin{array}{l}\text { wuen warin } \\
\text { orin }\end{array}$ & Wuen warin orin \\
\hline 2. & NK 03 & Semua orang & Semua orang & $\begin{array}{l}\text { ata mogan } \\
\text { sawen }\end{array}$ & Ata mogan sawen \\
\hline 3. & NK 05 & Rumah nenek & Rumah nenek & ina du'a orin & Ina du'a orin \\
\hline 4. & NK 06 & Suatu hari & Suatu hari & leron ha & Leron ha \\
\hline 5. & NK 07 & Banyak orang & Banyak orang & ata riwun & Ata riwun \\
\hline 6. & NK 08 & $\begin{array}{l}\text { Langsung } \\
\text { makan }\end{array}$ & $\begin{array}{l}\text { Langsung } \\
\text { makan }\end{array}$ & gea golo & Gea golo \\
\hline 7. & NK 09 & Sudah siang & Sudah siang & lero detu ba’a & Lero detu ba'a \\
\hline 8. & NK 10 & Suara motor & Suara motor & motor lin & Motor lin \\
\hline
\end{tabular}

Berdasarkan tabel tersebut dapat diketahui bahwa terdapat 8 frase dari karangan peserta didik yang mengalami interferensi. Interferensi frase ini terjadi karena berbagai alasan. Salah satunya adalah dalam bahasa Indonesia mengenal hukum DM (diterangkan menerangkan) dan MD (menerangkan diterangkan), sedangkan dalam bahasa Sikka hanya mengenal hukum DM (diterangkan menerangkan), STA (dalam Wikipedia).

Frase merupakan satuan gramatikal yang berupa gabungan kata yang bersifat nonpredikatif, atau lazim juga disebut gabungan kata yang mengisi salah satu fungsi sintaksis di dalam kalimat (Chaer, 2012, 222). Dari data tersebut dapat diketahui bahwa pekerjaan peserta didik mengalami interferensi frase. Misalnya pada (NK 02) rumah keluarga, bila diterjemahkan dalam bahasa Sikka maka wuen warin orin. Tidak mungkin ditulis orin wuen warin. Begitu juga dengan 
P-ISSN 2580 - 7781

E-ISSN $2615-3238$

(NK 03) sетиа orang, bila diterjemahkan dalam bahasa Sikka maka ata mogan sawen. Tidak mungkin ditulis mogan sawen ata. Pada (NK 05) rumah nenek, bila diterjemahkan dalam bahasa Sikka maka ina dua'a orin. Tidak bisa ditulis orin ina du'a. Sedangkan, (NK 06) suatu hari, bila diterjemahkan dalam bahasa Sikka maka leron ha. Tidak bisa ditulis ha leron.

Hal senada juga terjadi pada (NK 07) banyak orang, bila diterjemahkan dalam bahasa Sikka maka ata riwun. Tidak bisa ditulis riwun ata. Ada pula (NK 08) langsung makan, bila diterjemahkan dalam bahasa Sikka maka gea golo. Tidak bisa ditulis golo gea. Begitu juga dengan (NK 09) sudah siang, bila diterjemahkan dalam bahasa Sikka maka lero detu $b a^{\prime} a$. Tidak bisa ditulis $b a^{\prime} a$ lero detu. Hal seperti ini juga terjadi pada (NK 10) suara motor, bila diterjemahkan dalam bahasa Sikka maka motor lin. Tidak bisa ditulis lin motor.

Hal ini terjadi karena dalam bahasa Indonesia mengenal hukum DM (diterangkan menerangkan) dan MD (menerangkan diterangkan), sedangkan dalam bahasa Sikka hanya mengenal hukum DM (diterangkan menerangkan). Oleh karena itu, ada 8 interferensi frase dalam karangan peserta didik tersebut.

\section{KESIMPULAN}

Berdasarkan uraian pada analisis dan pembahasan data hasil penelitian, dapat disimpulkan bahwa terdapat interferensi sintaksis bahasa daerah Sikka pada karangan narasi peserta didik. Interferensi ini mempunyai pengaruh terhadap penggunaan bahasa Indonesia. Hasil analisis tersebut menunjukkan bahwa masuknya unsur bahasa Sikka dalam frase, pola struktur klausa dan kalimatnya sangat mempengaruhi penggunaan bahasa Indonesia peserta didik. Struktur penulisannya tidak efektif atau tidak bertaruran. Sedangkan, pola struktur penulisan sebuah kalimat yang tepat adalah subjek, predikat, objek dan keterangan. Dari kejadian ini dapat dikatakan bahwa peserta didik memiliki pengetahuan yang minim mengenai pola struktur penulisan bahasa Indonesia yang baik dan benar. Begitu juga pada interferensi frase, penyebab terjadinya karena dalam bahasa Indonesia mengenal hukum DM (diterangkan 
P-ISSN 2580 - 7781

E-ISSN $2615-3238$

menerangkan) dan MD (menerangkan diterangkan), sedangkan dalam bahasa Sikka hanya mengenal hukum DM (diterangkan menerangkan). Oleh karena itu, karangan peserta didik mengalami interferensi sintaksis yaitu kalimat, klausa dan frase.

\section{DAFTAR PUSTAKA}

Devianty, R. (2017). Bahasa sebagai cermin kebudayaan. Jurnal tarbiyah, 24(2).

Kasni, N. W. (2016). Klausa Keterangan Dalam Bahasa Sumba Dialek Waijewa (BSDW). RETORIKA: Jurnal Ilmu Bahasa, 2(1), 95-109.

Rahimah, A., \& Syahrul, R. (2015). Interferensi Bahasa Mandailing dalam Bahasa Indonesia Tulis Siswa Kelas VIII MTS Baharuddin Kecamatan Batang Angkola Kabupaten Tapanuli Selatan. Bahasa, Sastra, dan Pembelajaran, 3(1).

Rahmayana, R., Mantasiah, R., Hasmawati, H., \& Muddin, M. (2018). INTERFERENSI POLA KALIMAT BAHASA INDONESIA TERHADAP KETERAMPILAN BERBICARA BAHASA JERMAN SISWA. Eralingua: Jurnal Pendidikan Bahasa Asing dan Sastra, 2(2).

Ramendra, D.P. 2013. "Variasi Pemakaian Bahasa pada Masyarakat Tutur Kota Singaraja”. Jurnal Ilmu Sosial dan Humaniora. Vol.2, No.2, Oktober, hal 275-287.

Saenab, S. (2018). Interferensi Sintaksis Bahasa Bugis Terhadap Penggunaan Bahasa Bahasa Indonesia dalam Interaksi Belajar Mengajar Siswa Kelas VIII SMPN 2 Unggulan Maros. Seminar Nasional Kajian Bahasa, Sastra, dan Pengajarannya (SEMNAS KBSP) V 2018.

Sumarsih, S., \& Hum, M. (2017). Analisis Interferensi Pada Laporan Perjalanan Siswa Kelas VIII SMP Negeri 1 Kartasura Dan Implikasinya Dalam Pembelajaran Menulis (Doctoral dissertation, Universitas Muhammadiyah Surakarta).

ZULKIFLI, Z. (2018). Interferensi Morfologi Bahasa Indonesia dalam Karangan Bahasa Makassar Siswa Kelas VIII SMP Negeri 1 Tompobulu Kabupaten Gowa (Doctoral dissertation, UNIVERSITAS NEGERI MAKASSAR). https://id.m.wikipedia.org (03 Mei 2020) 